\title{
PERFORMANCE EVALUATION OF DOHUK WATER TREATMENT PLANT
}

\author{
JWAN N. HASSAN \\ Dept. Civil Engineering,College of Engineering,University of Duhok, Kurdistan Region-Iraq
}

\begin{abstract}
Dohuk water treatment plant supplies drinking water to duhok city with $11000 \mathrm{~m}^{3} / \mathrm{hr}$ capacity and serving around $\mathbf{6 5 0 0 0 0}$ capita. In this study, the plant performance evaluated through studying the turbidity efficiency removal of each unit in the plant as well as the overall removal efficiency. The data were collected from daily laboratory water quality analysis reports covering the period from 1-10-2010 through 31-10-2013 with total number of samples 825 (excluding the days were the plant was out of duty or samples did not taken). Statistical Analysis techniques shows that the water treatment plant performance was acceptable and about $(97.82 \%)$ of the supplied water match the Iraqi drinking water standards. All units are efficient except the pre-sedimentation tank which is insufficient.
\end{abstract}

KEYWORDS: Water Treatment plant, turbidity, raw water.

\section{INTRODUCTION}

$\mathbf{T}$ The water treatment plant's purpose is to supply water for the domestic use, it is desirable to remove any materials, either in suspension or in solution, which are harmful. It is unconditionally essential to remove, deactivate, or kill any harmful microorganisms and to remove harmful chemical matters. The water treatment plant performance evaluation can be used to improve the operations of the water treatment plant processes $(1,8)$.

The hazy look of water caused by the existence of suspended and colloidal substance which is called turbidity. Turbidity measurement is indicating the clarity of water. The unit of measuring turbidity is a Nephelometric Turbidity Unit (NTU). World Health Organization (WHO) has set the standard value for the residual turbidity in drinking water at 5 (NTU) which is the same value for Iraq drinking water standards. Clay or other inert suspended particles in and of themselves may not adversely affect health, but water containing such particles may require treatment to make it suitable for disinfection. Therefore, turbidity reduces disinfection efficiency by consuming the disinfectant and shielding the microorganisms $(2,4,9)$.

ElDib and Elbayoumy (2003) investigate the treatment plant in Dakahlia (Meet Fares). The evaluation performed by studying the engineering design to ensure matching of drinking water quality standards and codes. biological, chemical and bacteriological analysis were conducted to perform the evaluation. The results show that the importance of precise engineering design and the need for continuous monitoring and analysis of each unit performance (3) .

Al-Ani and Kadum (2011) studied the turbidity removing efficiency of Sharq Dijila water treatment plant for the period of 1-4-2001 to 31-32004. The study found that the filter unit operation is within the acceptable range with percentage of $100 \%$ and $45 \%$ respectively. Treated water turbidity averaged between 0.4-9.5 NTU. The 2day and 30-day moving average of the supplied water was within the permissible limits of $98 \%$, $98.6 \%$, and $98.6 \%$ respectively due to the Iraqi Drinking Water Standard, USEPA (5) .

Also Al-Ani and Kadum (2013) studied the performance of Samarra City water treatment plant. The study covered the period of December, 2004 to May, 2005. The results show that increasing in raw water turbidity result in an increase in turbidity removal efficiency. $\mathrm{pH}$ values and TDS concentrations of supplied water are within Iraqi, EPA and WHO Specifications (6) .

Janna and Al-Samawi (2014) studied the performance of Al-Karkh water treatment plant in Baghdad. Their collected data covered the period from January 2000 to December 2002. The water turbidity data and 1-day average study base showed that the water treatment plant performance was found to be well above (98\%) according to 
the Iraqi drinking water standards. While the 30day moving average study shows that the quality of the treated water was (68\%) exceeded the Unites State Environmental Protection Agency (USEPA) standards and the 2-days moving average samples showed that $(99 \%)$ matched the standards and operating water treatment plant with a regular maintenance for the different units was highly recommended (7) .

The regular monitoring of treated water quality of water purification systems, and the performance evaluation of its unit operations and processes is very essential for the consumer health. Therefore, this study was designed to study the treatability performance of the Duhok WTP. Since, the turbidity has been considered as the most reliable and standard parameters for the performance evaluation of the treatment plants.

\section{The Project Area}

Dohuk city lies in the governorate of Iraqi Kurdistan. The location of the city is strategical because it lies at the junction of the borders of Iraq, Turkey and Syria in the heart of Iraqi Kurdistan Region.

Dohuk lies in the midst of hills, valleys and mountains. It is somewhat in the shape of irregular rectangle, and the 43 East Longitude passes through the city centre and divides the governorate in half. The governorate itself lies in Northern Temperature Zone between the East Longitude of $4310^{\prime} \mathrm{E}$ and $4410^{\prime} \mathrm{E}$ and the North Latitudes of $3640^{\prime} \mathrm{N}$ and $3720^{\prime} \mathrm{N}$.

Dohuk is categorized by its different topography, which includes very high, sharp and complex mountain ranges which forms natural political borders with Turkey in the north, in disparity to its plains in the southern part of the governorate. Its area is approximately 10.715 square kilometres. The town of Dohuk is located in the north-east of the national territory of Iraq, in the Kurdish area. Figure (1) shows the location of Dohuk city.

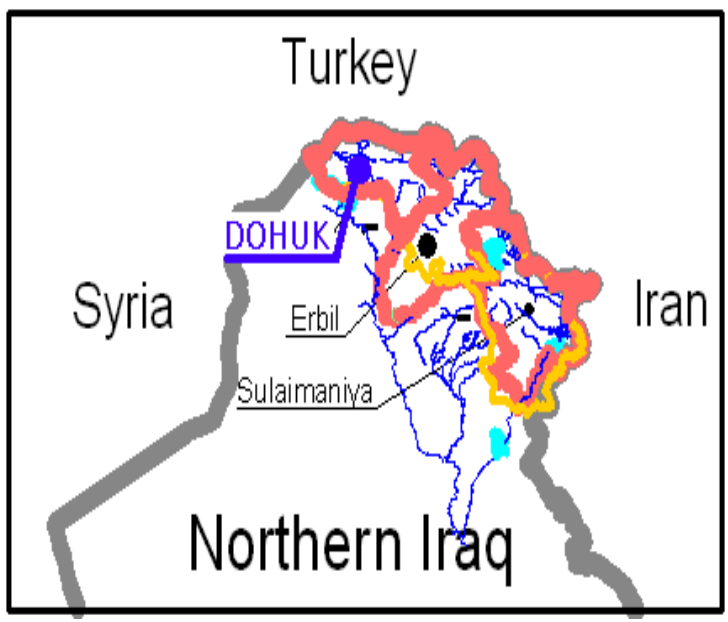

Fig.(1): The Location of Dohuk City.

\section{Topography}

Dohuk, the capital town of the governorate of Dohuk, is located in the north-west of Iraq, about $80 \mathrm{~km}$ north of Mosul. The town is embedded between two mountains in the north, called Spi and Gully, and the Zawa Mountain in the south. Between Spi - and Gully Mountain, rising up in the north, the Dohuk dam has been erected in 1984. The Zawa mountain surrounds the town area in the east in arched form. The highest location at Zawa mountain in the south is about 1050 m.a.s.l. (meters above sea level), the mountain peaks, at Spi - and Gully mountain in the north, are approximately 950 respectively 1000 m.a.s.l. The urban area of Dohuk is sloping towards the west down to about 400 m.a.s.l. The small valley between the points of contact between the Zawa - and the Gully mountain in the north-east leads to Bessery village. The west-east extension of today's town area is approximately $12 \mathrm{~km}$ and the north-south extension is about 4 $\mathrm{km}$.

Two small riverlets, the Gully river starting from the Dohuk lake in the north and the Bessery 
stream coming from the east, are crossing the town area. These two rivers are combined to one river in Nohedra - district close to the University. Both streams are flowing south-west towards Qassara district and discharge their water into the Mosul lake. During hot summertime these streams are almost dried up, only during wintertime, with initial rainfalls expected around November, they deliver substantial quantities of surface water.

The highest locations in the existing water distribution system are the Maarth well in the south - east at about 680 m.a.s.l. and the existing Shakhky water project in the north of the distribution system (two deep wells and concrete reservoir) at about 670 m.a.s.l.

\section{Climate}

Mean annual temperatures in Duhok governorate vary abruptly with elevation, decreasing as one rises the central massif. The summers in the lower elevations can be oppressively hot and semi-nude, while it stays pleasantly cool in regions deep inside the mountains. The winters, except in small marginal regions facing the plains, are bitterly cold and snowy. During the hot summer month from June until August the temperature reaches up to $55^{\circ} \mathrm{C}$ temperatures monitored during summer 2003 by meters of customers indicated even $59^{\circ} \mathrm{C}$. In winter the temperature drops to $5-10^{\circ} \mathrm{C}$ below zero. The snowfall in winter is recorded for the hilly area (above 600 m.a.s.l.). Occasionally snow covers of up to $500 \mathrm{~mm}$ are recorded. The arid and continental climate is characterized by very short autumn and spring.

During the observation period (1975 to 2003) no rainfalls have been recorded for the months of July, August and September. In very dry years even in May, June and October no rainfalls were registered. The annual average rainfall quantity for the year 1975 until 2003 is $510 \mathrm{~mm}$.
About $90 \%$ of the annual rainfall occurs between November and April, most of it in the winter months from December through March. The remaining six months, particularly the hottest ones of June, July, and August, are dry.

\section{Dohuk Water Treatment Plant}

Dohuk water treatment plant's capacity is $11000 \mathrm{~m}^{3} / \mathrm{hr}$ serving around 650000 customers. Figure (2) represents the site plan of the treatment plant in which the raw water which will be taken from Tigris river will be pumped to the Inlet Structure of Treatment Plant. After breaking the excess energy of raw water, it will be aerated when falling from the cascades. Chlorination will be done in the outlet channel then aerated raw water will pass through to the primary sedimentation tank then to the rapid mixing unit.

Alum, and if necessary lime or acid for $\mathrm{pH}$ regulation will be added and mixed rapidly in this unit. The water then enters to the slow mixing unit's compartments distribution channel. The paddles of the mixers turn slowly for the flocculation process and their movement causes the small particles to collide and stick together and passing through clarifiers for settling.

From clarifiers settled water will pass to rapid sand filters removes suspended and microorganisms matter from the water

Filtered water collected from bottom of the filter is given to chlorine contact tank for disinfection and $\mathrm{pH}$ correction before usage as domestic water.

Raw water which has been disinfected and in the quality of drinking water is taken from treated water tank and transmitted to pumping station.

In addition of these process units, there will be some auxiliary units such as chemical, chlorination, administration and mass buildings and guard's cabin for the needs of process itself and other necessities at the plant area. 


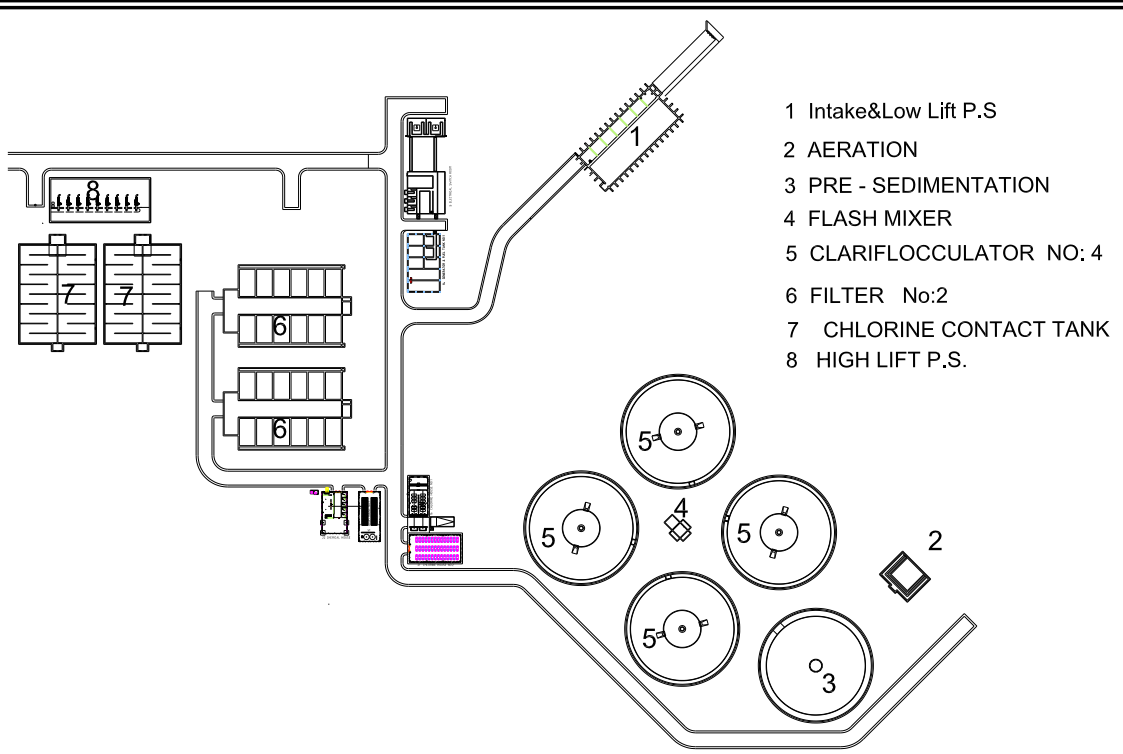

Fig. (2): Dohuk WTP Site Plan

\section{Data Collection}

In order to evaluate the performance of Dohuk WTP, samples were collected from the raw, aeration, sedimentation, clarified, filtered, and supplied water. Analysis was carried out in the laboratory of the treatment plant. The data were collected from daily laboratory water quality analysis reports covering the period from 1-102010 through 31-10-2013 with total number of samples 825 (excluding the days were the plant was out of duty or samples did not taken).

\section{RESULTS AND DISCUSSION}

Figure (3) shows daily turbidity observations time series plot raw water samples. The figure shows a wide range variation in turbidity values within one month and observing high turbidity during rainy seasons. Table 1 shows descriptive statistics of raw water turbidity data (Tigers river). the ranges of the turbidity are widely varied from 10 to 4079 NTU , standard deviation of 296.679 and the mean value is 171.421 NTU, the coefficient of variation $\mathrm{Cv}$ is $173.07 \%$ which means a wide dispersion in the raw water turbidity values and for this reason primary sedimentation tank added to the WTP. Figures (4) and (5) shows the frequency and cumulative frequency of raw water turbidity, it is clear that 638 of 825 days $(77.33 \%)$ the turbidity is less than 200 NTU and about $97.82 \%$ is less than 1000 NTU. 


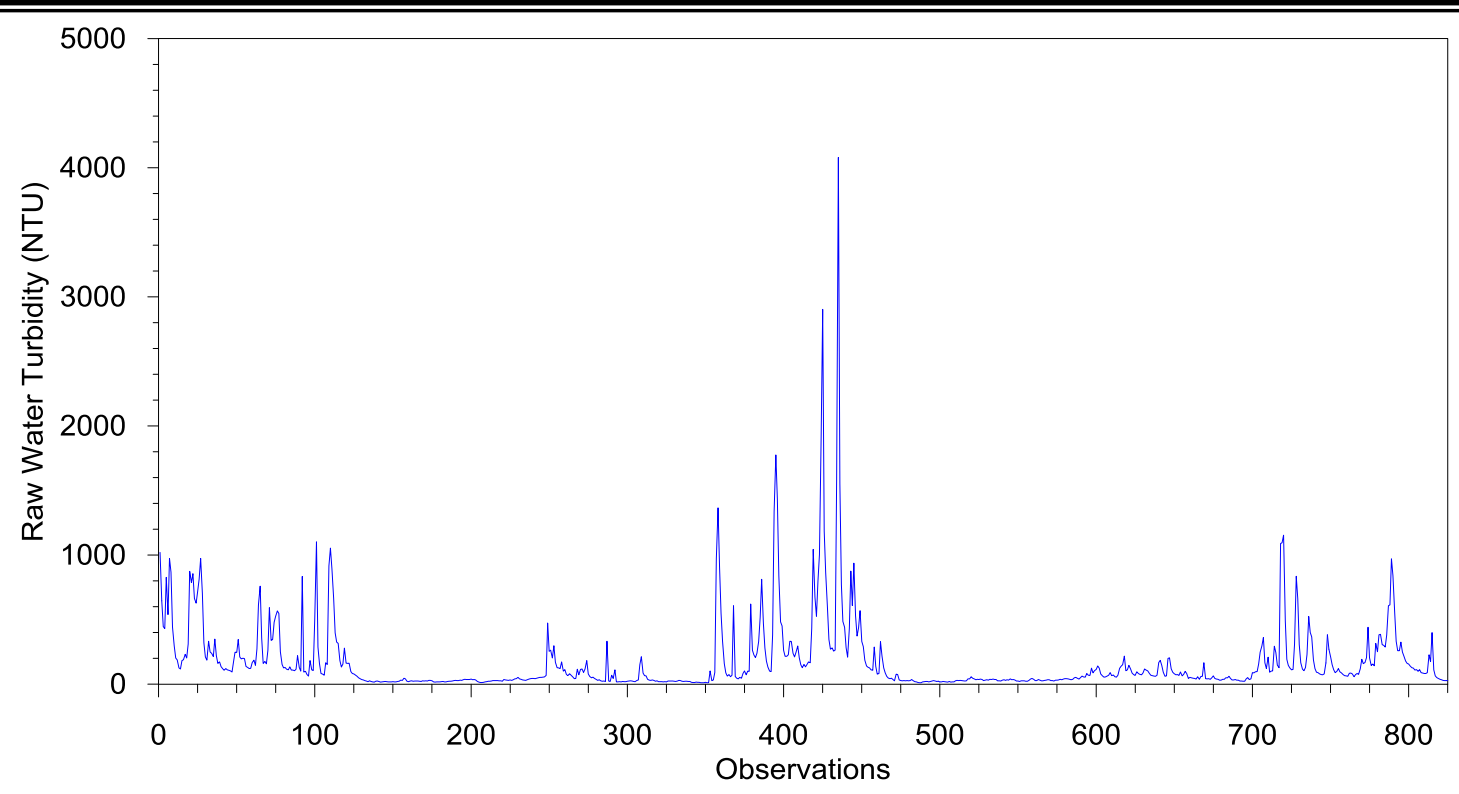

Fig. (3): Daily Raw Water Turbidity of Dohuk WTP

Table (1): Raw Water Turbidity Descriptive Statistics

\begin{tabular}{cccccccc}
\hline & N & Min. & Max. & Mean & Std. & $\begin{array}{c}\text { Skew } \\
\text { ness }\end{array}$ & Kurtosis \\
& & & & & & & \\
\hline Raw Water Turbidity & 825 & 10.00 & 4079.00 & 171.421 & 296.674 & 5.460 & 49.478 \\
\hline Valid N (listwise) & 825 & & & & & & \\
\hline
\end{tabular}

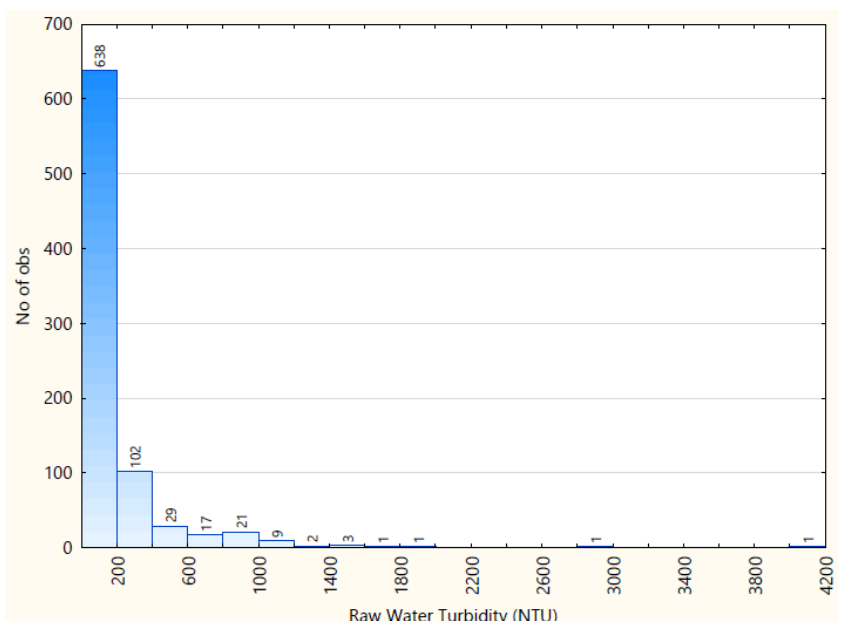

Fig. (4): Frequency of Raw Water Turbidity 


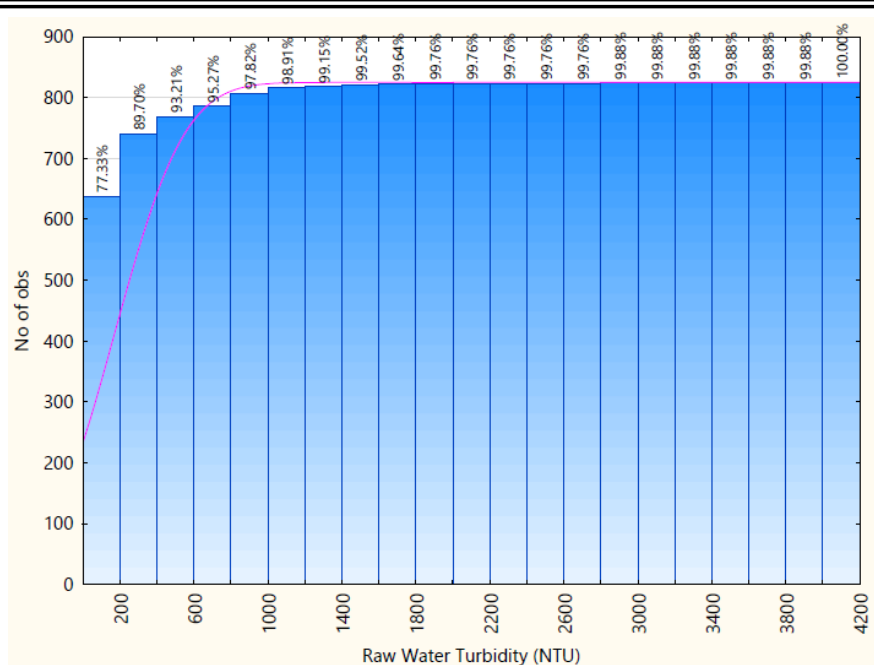

Fig. (5): Cumulative Frequency of Raw Water Turbidity

Figure (6) shows daily turbidity observations time series plot pre-sedimentation tank Water samples. The figure follow the variation in turbidity values of raw water. Table 2 shows descriptive statistics of the data, widely varied from 6 to 3963 NTU, standard deviation of 200.650 and the mean value is $116.139 \mathrm{NTU}$, the coefficient of variation $\mathrm{Cv}$ is $172.76 \%$ which means a wide dispersion in the turbidity values. Figures (7) and (8) show the frequency and cumulative frequency of the turbidity, it is clear that 699 of 825 days $(84.73 \%$ ) the turbidity is less than $200 \mathrm{NTU}$ and about $99.52 \%$ is less than 1000 NTU. The pre-sedimentation tank reduces the turbidity but it fails at high turbidity.

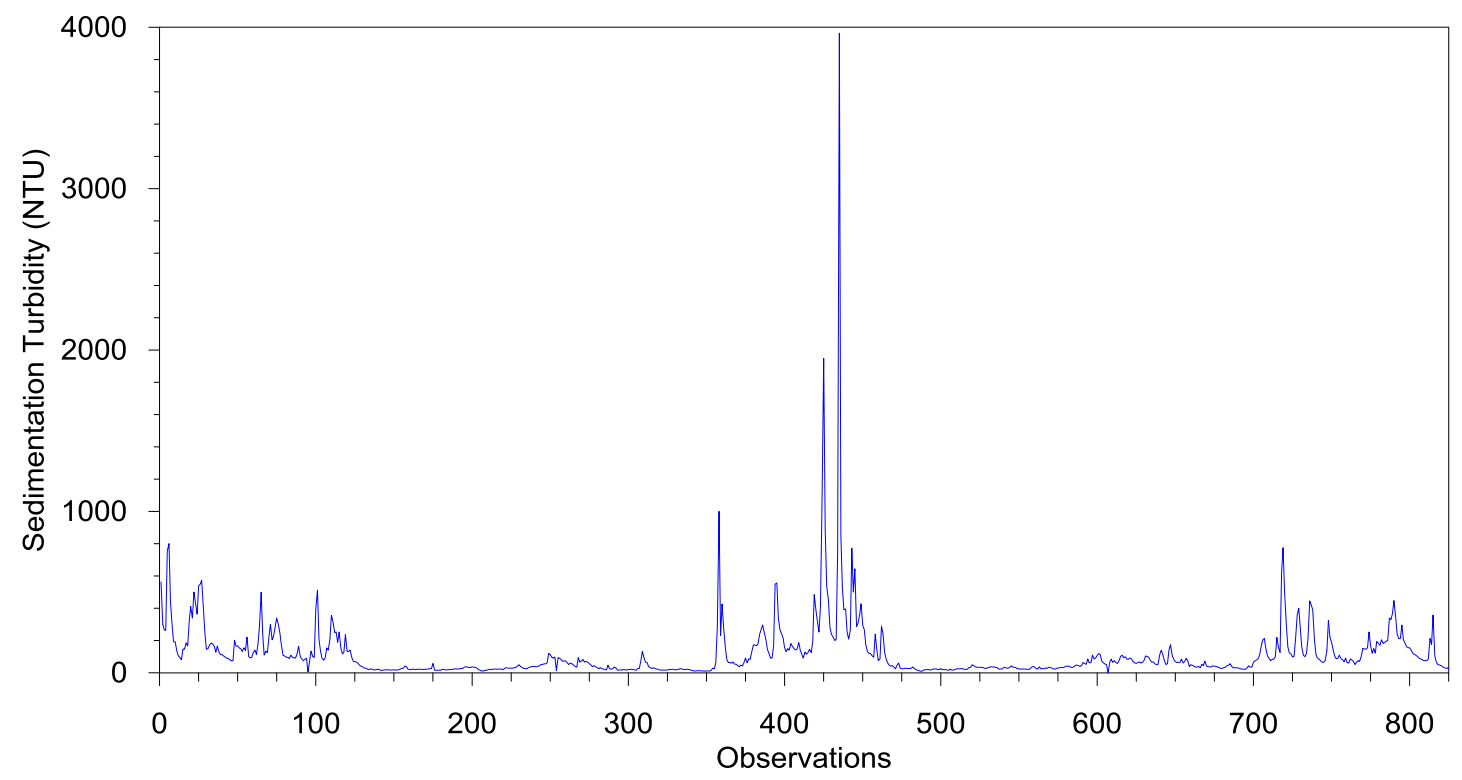

Fig. (6): Daily Pre-Sedimentation Tank Water Turbidity of Dohuk WTP

Table (2):Pre-Sedimentation Tank Water Turbidity Descriptive Statistics

\begin{tabular}{lcccccccc}
\hline & & N & Min. & Max. & Mean & Std. & $\begin{array}{c}\text { Skewn } \\
\text { ess }\end{array}$ & Kurtosis \\
\hline $\begin{array}{l}\text { Sedimentation } \\
\text { Water Turbidity }\end{array}$ & Tank & 825 & 6.00 & 3963.00 & $\begin{array}{l}116.13 \\
9\end{array}$ & 200.650 & 10.370 & 173.653 \\
\hline
\end{tabular}




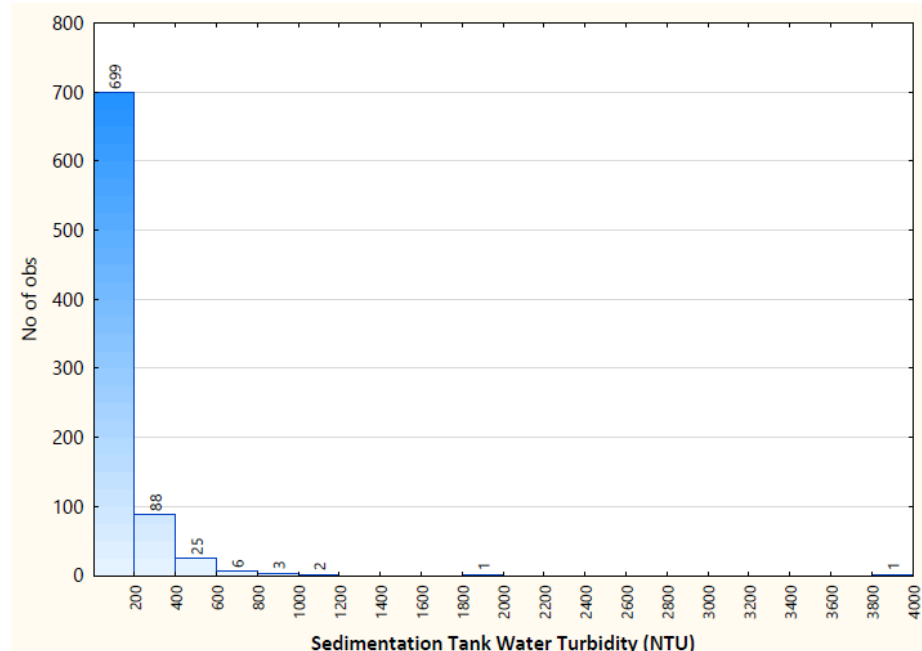

Fig. (7): Frequency of Pre-Sedimentation Tank Water Turbidity

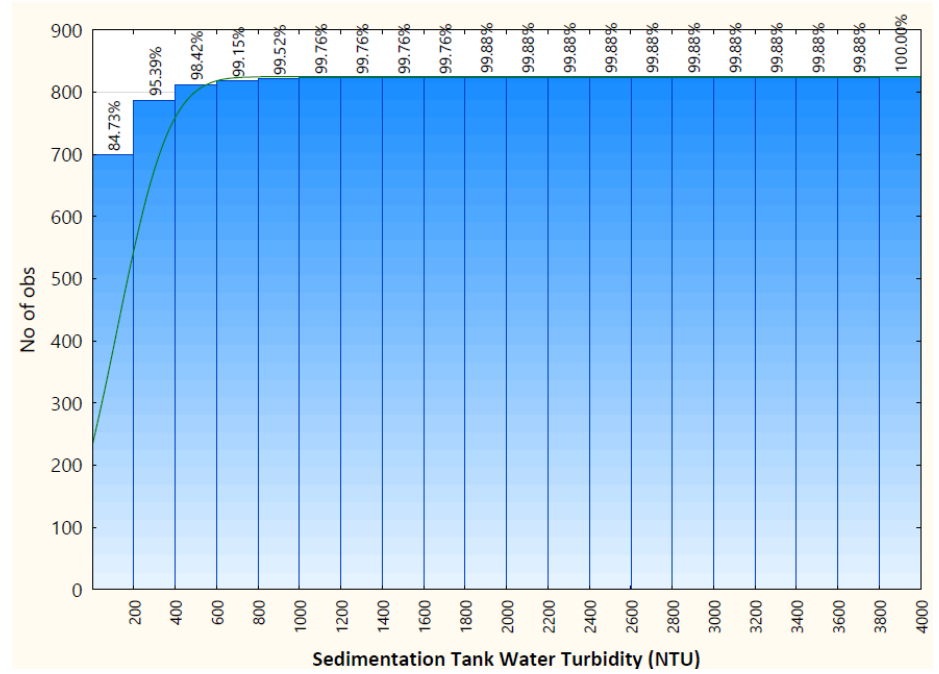

Fig. (8): Cumulative Frequency of Pre-Sedimentation Tank Water Turbidity

Figure (9) shows daily turbidity observations time series plot Clarifier Water samples. Table 3 shows descriptive statistics of the data. The turbidity ranges from 5.70 to 112.80 NTU, standard deviation of 7.031 and the mean value is 18.865 NTU, the coefficient of variation $\mathrm{Cv}$ is $37.27 \%$ which means a less dispersion in the turbidity values. Figures (10) and (11) show the frequency and cumulative frequency of the turbidity, it is clear that 790 of 825 days (95.76 $\%$ ) the turbidity is less than 30 NTU and about $99.76 \%$ is less than 50 NTU. The Clarifier reduces the turbidity distinctively. 


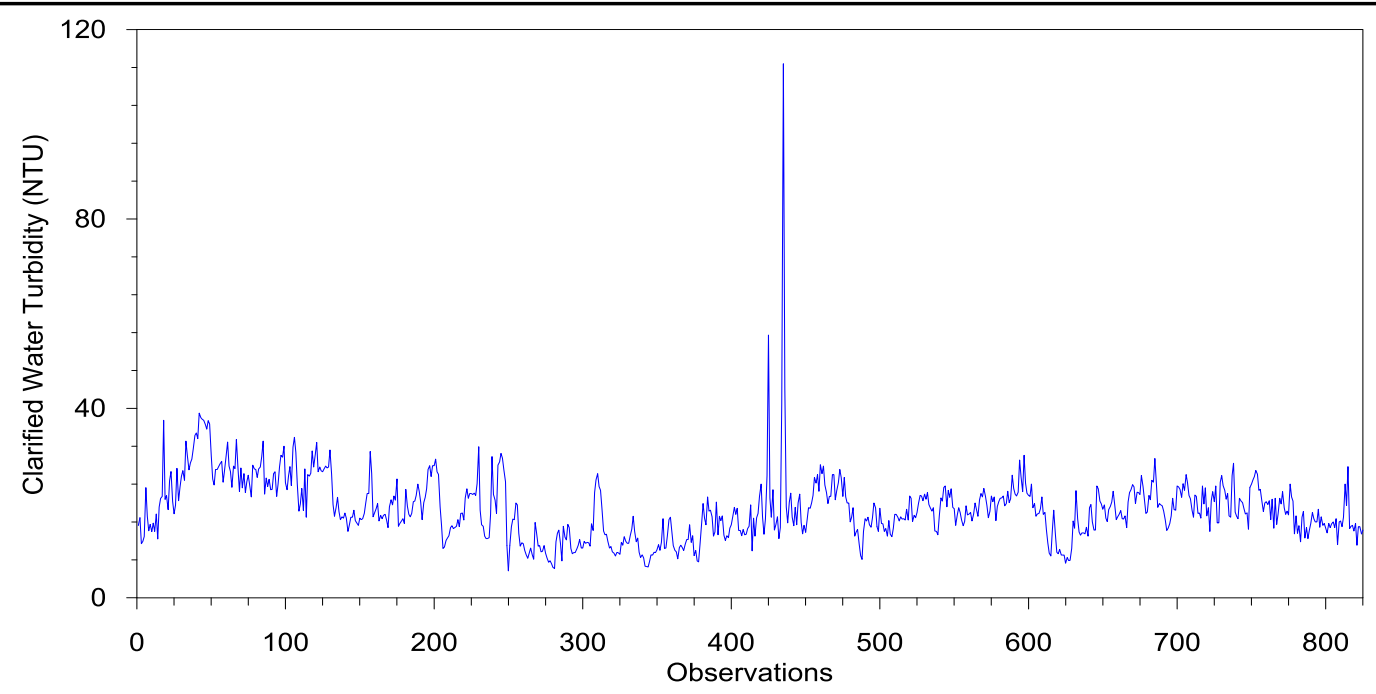

Fig. (9): Daily Clarified Water Turbidity of Dohuk WTP

Table (3): Clarified Water Turbidity Descriptive Statistics

\begin{tabular}{lccccccc}
\hline & N & Min. & Max. & Mean & Std. & $\begin{array}{c}\text { Skewne } \\
\text { ss }\end{array}$ & Kurtosis \\
& & & & & & & \\
\hline Clarified Water Turbidity & 825 & 5.70 & 112.80 & 18.865 & 7.0315 & 3.386 & 38.795 \\
\hline Valid N (listwise) & 825 & & & & & & \\
\hline
\end{tabular}

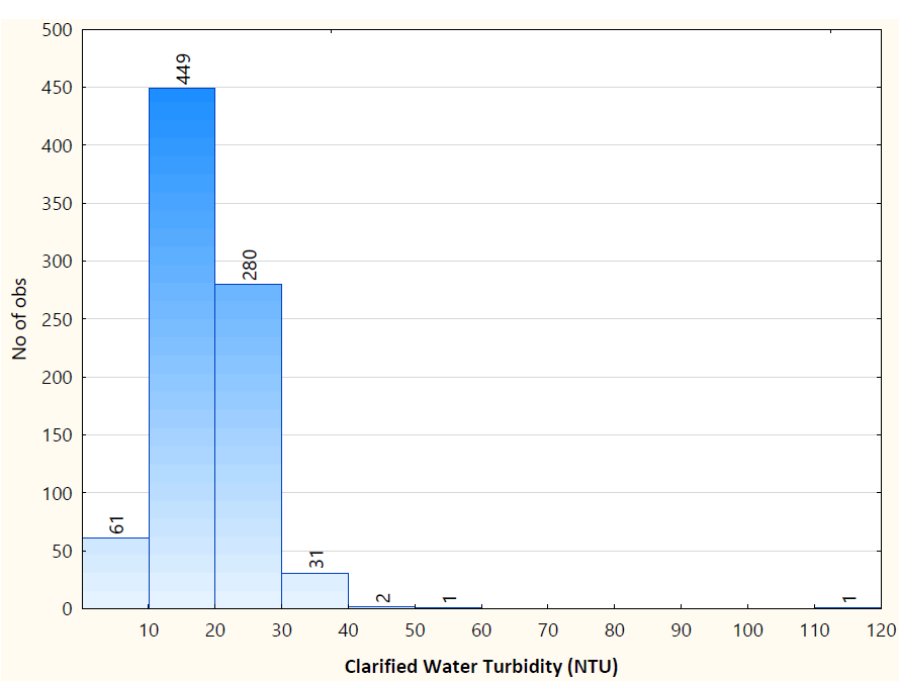

Fig. (10): Frequency of Clarified Water Turbidity 


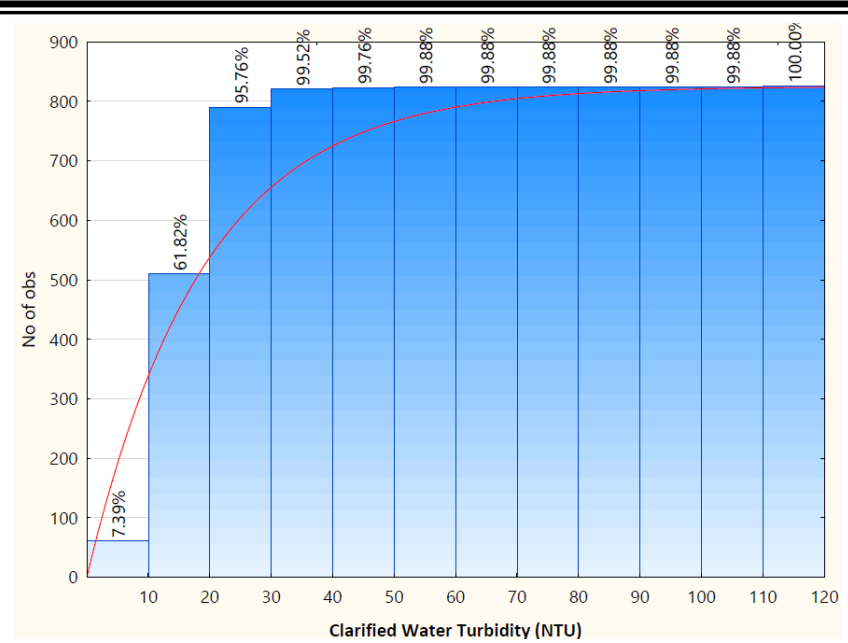

Fig. (11): Cumulative Frequency of Clarified Water Turbidity

Figure (12) shows daily turbidity observations time series plot Filtered Water samples. Table 4 shows descriptive statistics of the data. The turbidity level ranges from 0.1 to $25.60 \mathrm{NTU}$, standard deviation of 1.796 and the mean value is found to be 2.435 NTU, the coefficient of variation $\mathrm{Cv}$ is 73.74
$\%$ which means a less dispersion in the turbidity values. Figures (13) and (14) show the frequency and cumulative frequency of the turbidity, it is clear that 790 of 825 days $(95.76 \%)$ the turbidity is less than 5 NTU and about $99.15 \%$ is less than 10 NTU. The Filters reduces the turbidity distinctively.

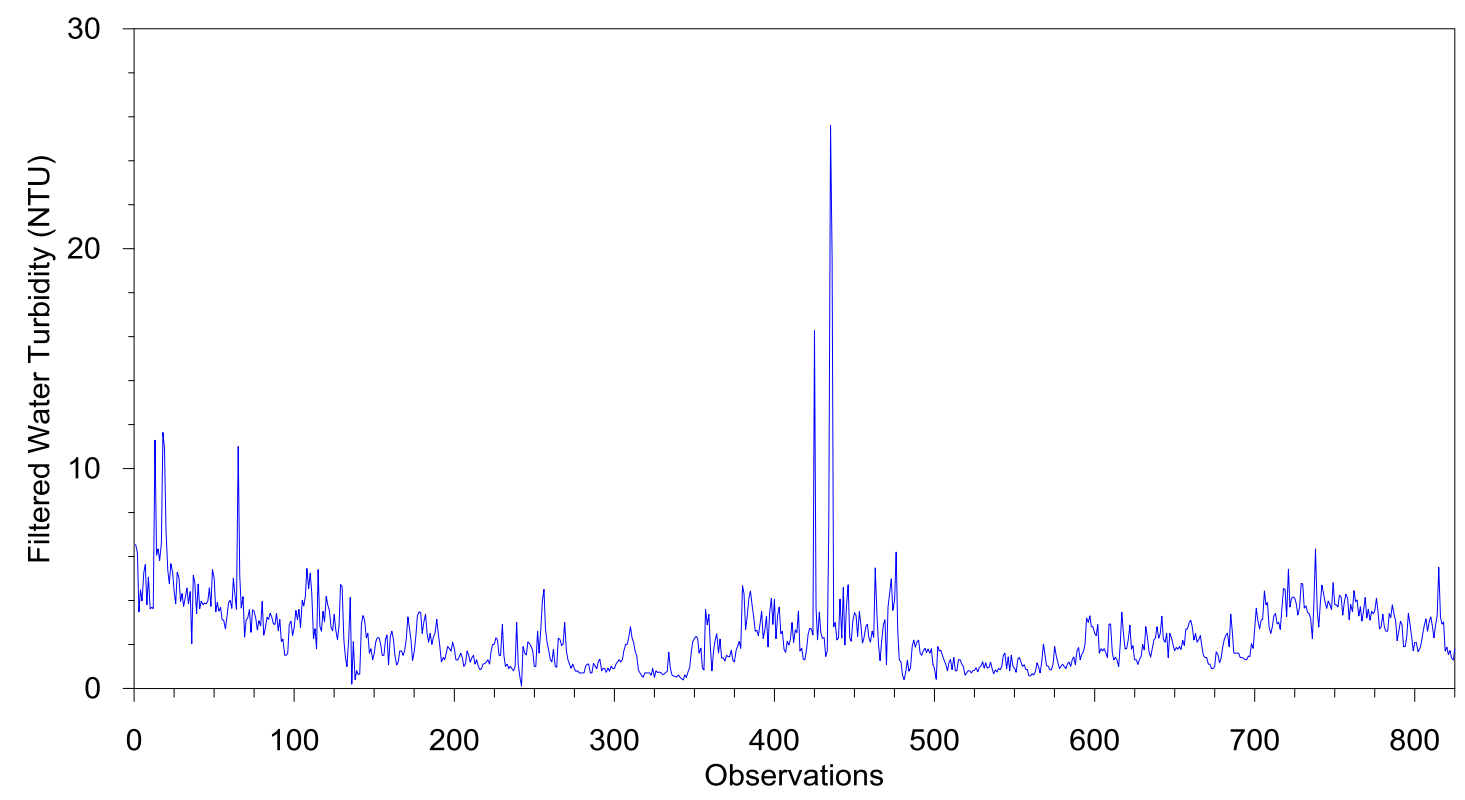

Fig. (12): Daily Filtered Water Turbidity of Dohuk WTP

Table (4): Filtered Water Turbidity Descriptive Statistics

\begin{tabular}{lccccccc}
\hline & N & Min. & Max. & Mean & Std. & $\begin{array}{c}\text { Skewne } \\
\text { ss }\end{array}$ & Kurtosis \\
& & & & & & & \\
\hline Filtered Water Turbidity & 825 & .10 & 25.60 & 2.4354 & 1.79616 & 4.977 & 48.884 \\
\hline Valid N (listwise) & 825 & & & & & & \\
\hline
\end{tabular}




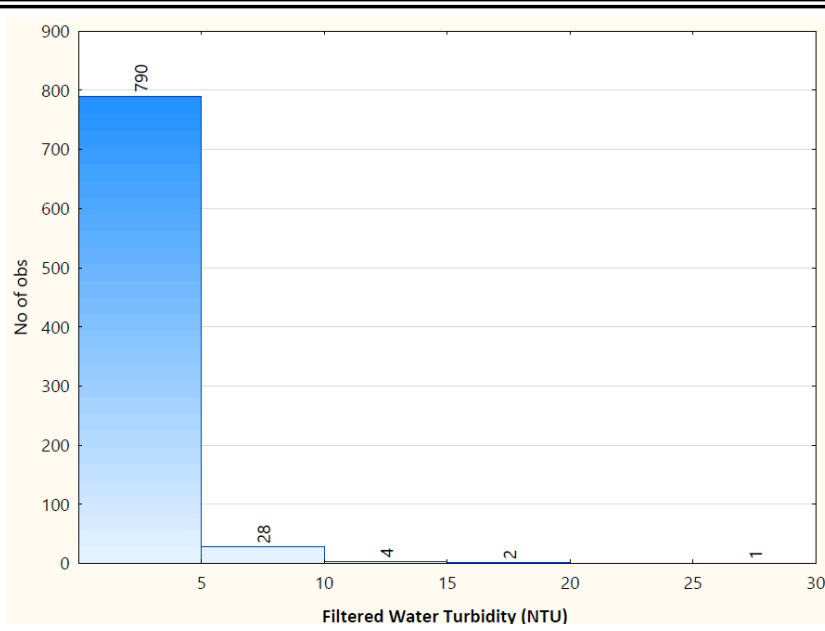

Fig. (13): Frequency of Filtered Water Turbidity

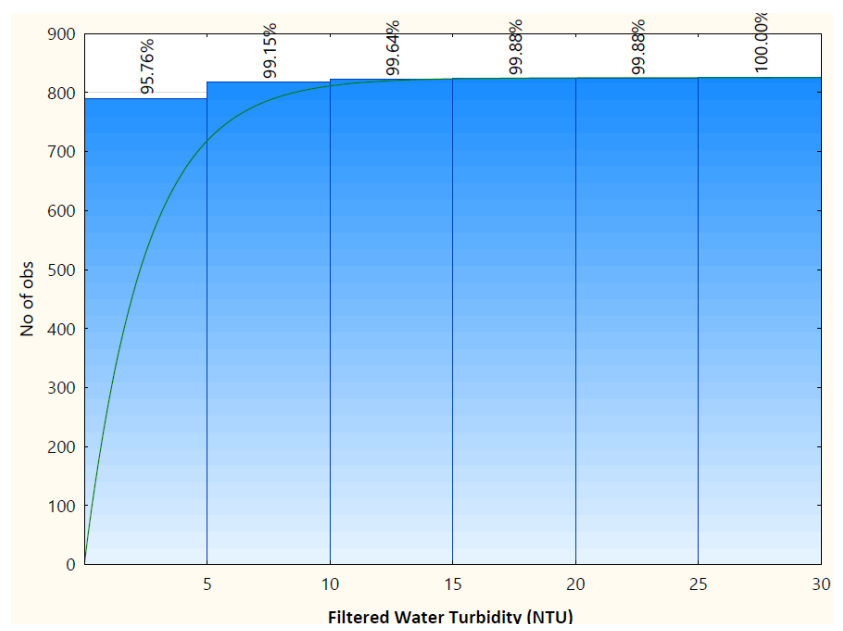

Fig. (14): Cumulative Frequency of Filtered Water Turbidity

Figure (15) shows daily turbidity observations time series plot Filtered Water samples. Table 5 shows descriptive statistics of the data. The turbidity ranges from 0.1 to $12.19 \mathrm{NTU}$, standard deviation of 1.291and the mean value is 2.224 NTU, the coefficient of variation $\mathrm{Cv}$ is $58.06 \%$ which means a less dispersion in the turbidity values. Figures (16) and (17) show the frequency and cumulative frequency of the turbidity, it is clear that 807 of 825 days $(97.82 \%)$ the turbidity is less than 5 NTU and about $99.88 \%$ is less than 10

NTU. 


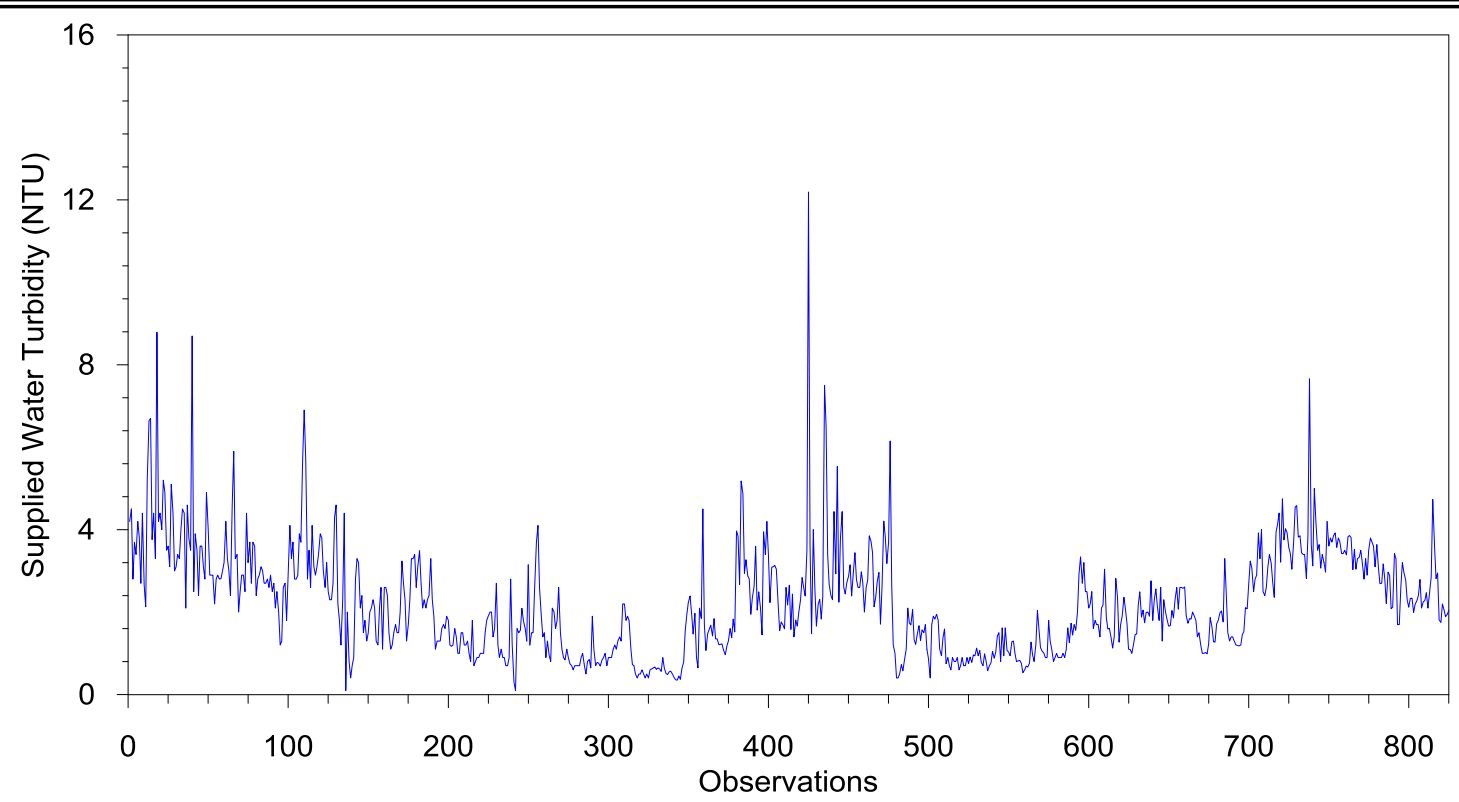

Fig. (15): Daily Supplied Water Turbidity of Dohuk WTP

Table (5): Supplied Water Turbidity Descriptive Statistics

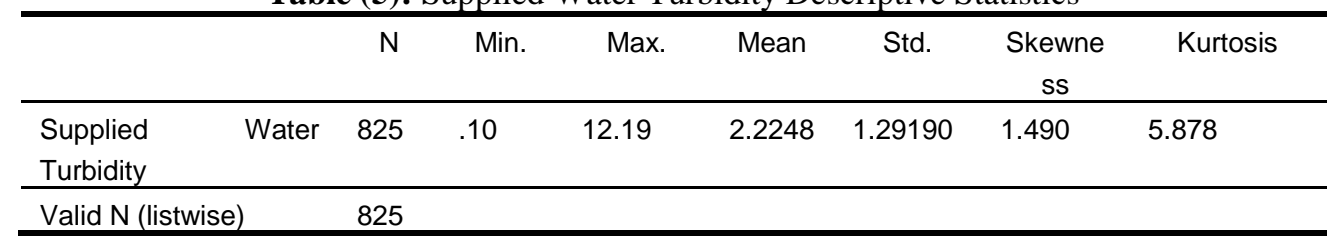

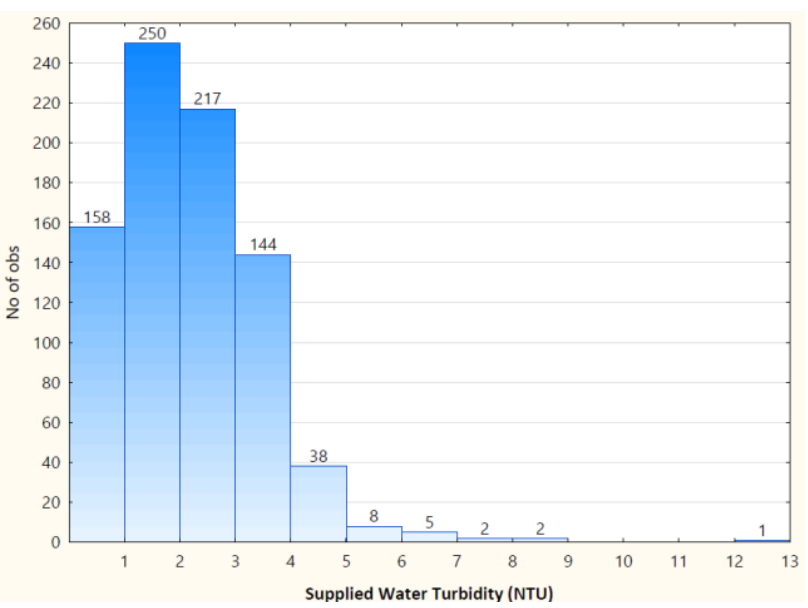

Fig. (16): Frequency of Supplied Water Turbidity 


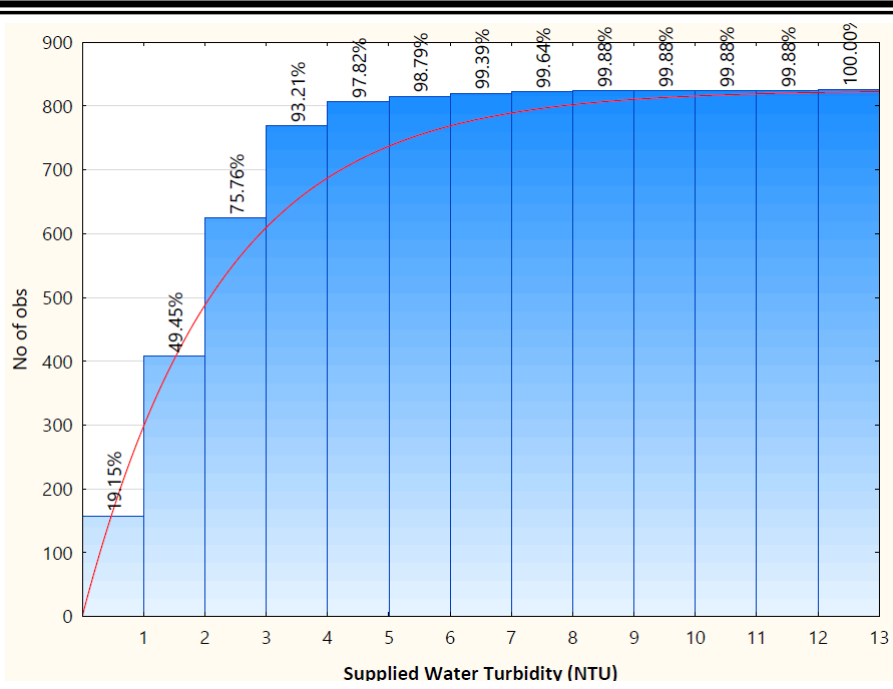

Fig. (17): Cumulative Frequency of Supplied Water Turbidity

Table (8) shows the matrix of correlation between turbidities of the WTP units in which significant relationship found between units.

Table (8): Correlation Matrix Between the Variables Correlations

\begin{tabular}{|c|c|c|c|c|c|c|}
\hline & & Raw & Sedimentation & Clarified & Filtered & Supplied \\
\hline & Pearson Correlation & 1 & $.915^{* *}$ & $.361^{* *}$ & $625^{* *}$ & $.500^{* *}$ \\
\hline \multirow[t]{3}{*}{ Raw } & Sig. (2-tailed) & & .000 & .000 & .000 & .000 \\
\hline & $\mathrm{N}$ & 825 & 825 & 825 & 825 & 825 \\
\hline & Pearson Correlation & $.915^{* *}$ & 1 & $.481^{* *}$ & $689^{* *}$ & $.506^{* *}$ \\
\hline \multirow[t]{3}{*}{ Sedimentation } & Sig. (2-tailed) & .000 & & .000 & .000 & .000 \\
\hline & $\mathrm{N}$ & 825 & 825 & 825 & 825 & 825 \\
\hline & Pearson Correlation & $361^{* *}$ & $.481^{* *}$ & 1 & $612^{* *}$ & $.513^{* *}$ \\
\hline \multirow[t]{3}{*}{ Clarified } & Sig. (2-tailed) & .000 & .000 & & .000 & .000 \\
\hline & $\mathrm{N}$ & 825 & 825 & 825 & 825 & 825 \\
\hline & Pearson Correlation & $625^{* *}$ & $689^{* *}$ & $.612^{* *}$ & 1 & $.835^{* *}$ \\
\hline \multirow[t]{3}{*}{ Filtered } & Sig. (2-tailed) & .000 & .000 & .000 & & .000 \\
\hline & $\mathrm{N}$ & 825 & 825 & 825 & 825 & 825 \\
\hline & Pearson Correlation & $.500^{* *}$ & $.506 *$ & $.513^{* *}$ & $835^{* *}$ & 1 \\
\hline \multirow[t]{2}{*}{ Supplied } & Sig. (2-tailed) & .000 & .000 & .000 & .000 & \\
\hline & $\mathrm{N}$ & 825 & 825 & 825 & 825 & 825 \\
\hline
\end{tabular}

**. Correlation is significant at the 0.01 level (2-tailed).

\section{CONCLUSIONS}

Daily turbidity supplied from different units of Duhok water treatment plant were studied to estimate the performance of the plant. The conclusions are as follows:

1. The raw water turbidity variation at the intake of Duhok WTP is too high. Turbidity levels fluctuate between 10 to 4079 NTU , standard deviation of 296.679 and the mean value is
171.421 NTU. The high values is appears during the rainy season.

2. The turbidity of pre-sedimentation tank Water samples ranges from 6 to 3963 NTU, standard deviation of 200.650 and the mean value is 116.139 NTU. It is clear that the unit has no significant effect on the turbidity values. This is because of very small detention time used in the design. 
3. The turbidity of clarified water ranges from 45.70 to $112.80 \mathrm{NTU}$ with a standard deviation of 7.031 and the mean value is 18.865 NTU. 99.76 $\%$ of the turbidity is less than 50 NTU which reduces the turbidity significantly.

4. The turbidity of filtered water ranges from 0.1 to $25.60 \mathrm{NTU}$ with a standard deviation of 1.796 and the mean value is found to be 2.435 NTU. the 5 turbidity in 790 of 825 days $(95.76 \%)$ the turbidity is less than 5 NTU.

5. The turbidity of supplied water ranges from 0.1 to 12.19 NTU with a standard deviation of 1.2916 and the mean value is 2.224 NTU. the turbidity in 807 of 825 days (97.82 \%) match Iraqi and WHO standards.

\section{REFRENCES}

1- John T. O'Connor, Tom O'Connor and Rick Twait, (2009) "Water Treatment Plant Performance Evaluations and Operations" Published by John Wiley \& Sons.

2- Mackenzie L. Davis (2010), "Water and 8 Wastewater Engineering Design: Principles and Practice", McGraw-Hill.

3- Ali A., Hashmi N. H., Baig N., Iqbal S., Mumtaz K., (2012), "Performance evaluation of the water treatment plants of Islamabad Pakistan", journal of Archives of Environmental Science, vol 6, pp 111-117.
EIDib M. A and Elbayoumy A., (2003), "EVALUATION OF A WATER TREATMENT PLANT PERFORMANCE CASE STUDY", Seventh International Water Technology Conference IWTC7 Egypt 1-3 April 2003.

5- Al-Ani F. H., Kadum W., (2011), "Evaluating the Performance of Sharq Dijila Water Treatment Plant", Al-Khwarizmi Engineering Journal, Vol. 7, No. 2, PP 55 - 67.

Al-Ani F. H., Awaid A., (2013 ), "An evaluation of Samarra city drinking water treatment plants", International Journal of Environmental Monitoring and Analysis; 1(5): 203-212.

7- Janna H., Al-Samawi A. , (2014), “ Performance Evaluation of Al- Karkh Water Treatment Plant in the City of Baghdad", International Journal of Advanced Research, Volume 2, Issue 10, 823-829.

- Steel, E.W., and McGhee, T.J. ,(1979),"Water Supply and Sewage", McGraw-Hill.

9- Iraqi Criteria and Standards for drinking water chemical limits, (2009), ICS: 13.060.20, IQS: 417:2009, second update 2009 for chemical and physical limits. 